\title{
Leveraging PhD Students to Support EdD Dissertation Writing
}

\author{
Sarah Capello, PhD \\ Judson University \\ sarah.capello@judsonu.edu
}

\begin{abstract}
Doctoral faculty have long advocated for writing support for doctoral candidates during the dissertation stage. However, schools of education are often challenged to provide organizational supports to assist struggling dissertators. EdD students in CPED institutions may need additional supports due to shorter time-todegree programs and full-time work commitments. This paper reports how one PhD student in a CPED institution acted as a dissertation consultant for $35 \mathrm{EdD}$ dissertators and successfully guided them through their dissertations. The author examines how her background in composition, experiences in educational research, and willingness to address socio-emotional needs contributed to this success and argues that PhD students in schools of education with similar backgrounds can take up dissertation consulting work as organizational supports for EdD dissertators. The mutual benefits of engaging in this work are discussed as is the potential for school-university partnerships stemming from PhD-EdD student collaboration during doctoral study.
\end{abstract}

\section{KEYWORDS}

dissertation, dissertation writing, peer review

Scholars suggest that doctoral students need writing support, especially at the dissertation stage (Brooks-Gillies et al., 2015; Queen \& Squires, 2011; Switzer \& Perdue, 2011), yet providing such supports can be challenging (Russell, 2002). For example, doctoral students may not be offered an academic writing class during coursework. University writing centers may not be staffed to handle the volume of work a dissertation requires or have specialists to offer field-specific methodological and content feedback. Peer feedback can be beneficial, but it requires students to have strong writing skills and the ability to diagnose problems and offer productive feedback, which not all students possess (Lowery et al., 2018). Finally, dissertation chairs often lack the time and inclination to teach academic writing skills or copyedit individual dissertations and may believe those duties fall outside their responsibility. Schools of education (SOEs) are not immune to these challenges and must consider ways of supporting doctoral students at the dissertation stage. While there is an extensive literature base on general dissertation writing (e.g., Becker, 2007; Booth et al., 2016; Kamler \& Thomson, 2008; Queen \& Squires, 2011), research on organizational supports for EdD dissertators has received less attention. This gap is important because EdD students face different challenges when accessing available dissertation writing supports. EdD programs were designed for working practitioners, so EdD students are tasked with balancing full-time work and program commitments. Their availability to receive dissertation writing support is limited to nonworking hours, and work schedules and family responsibilities may prevent dissertators from participating in peer writing groups, visiting the university writing center, or seeking help from faculty during office hours. Furthermore, online and hybrid programs may enroll distance learners who are infrequently or never on campus and have reduced opportunities to meet with and receive feedback from faculty, peers, and support staff. Finally, reimagined EdD programs, specifically those following the Carnegie Project on the Education Doctorate (CPED) framework (Carnegie Project on the Education Doctorate [CPED], 2019), are transitioning to shorter time-to-degree programs (Perry, 2015), so students are tasked with similar work as traditional EdD programs but they must complete that work in an abbreviated amount of time ${ }^{1}$. The implications of these shifts are clear-full-time employment commitments, the lack of comprehensive organizational supports, and shortened time-todegree programs can interact to exacerbate the challenge of dissertation writing for EdD students.

Within this context, a for-profit dissertation writing industry emerged (White, 2016) that includes a plethora of do-it-yourself dissertation writing guidebooks (e.g., Roberts, 2010) and online limited liability companies (LLCs) that offer dissertation editing services. Doctoral faculty have pushed back against this industry by arguing that the available dissertation advice books are largely reductionist, prescriptive, and patronizing (Kamler \& Thomson, 2008) and by questioning the ethics of hiring outside editors to rewrite or copyedit students' work (Bertram Gallant, 2016; White, 2016). While these critiques are fair, there is a tangible need in SOEs for ethical,
${ }^{1}$ Scholars have begun to rethink the EdD dissertation product and have suggested alternative forms of dissertation scholarship including horizontal collaboration, co- authorship, closer ties to problems of practice, and challenges to technical rationality (Kennedy et al., 2018). (

New articles in this journal are licensed under a Creative Commons Attribution 4.0 United States License. Program and is cosponsored by the University of Pittsburgh Press.

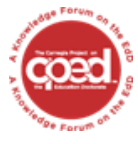

This journal is supported by the Carnegie Project on the Education Doctorate: A Knowledge Forum on the EdD (CPED) cpedinitiative.org 
innovative strategies to support EdD dissertators, yet few actionable alternatives have been operationalized. This paper suggests leveraging PhD students in SOEs who have backgrounds in composition and educational research as dissertation consultants to support their peers in EdD programs throughout the dissertation writing process. I engaged in this work for approximately four years as I was completing my $\mathrm{PhD}$ in a SOE. During that time, I consulted with $35 \mathrm{EdD}$ dissertators who all, with support, completed their dissertations and graduated. In this paper, I describe my background and experiences that led me to dissertation consulting and that allowed me to be successful in this role. Stemming from my experience, I offer suggestions for leveraging PhD students as organizational supports for EdD dissertators, describe the benefits of doing so, and examine the means necessary for this intervention to be successful.

\section{A PATHWAY TO DISSERTATION CONSULTING}

Before I began my work as a dissertation consultant, I took graduate courses in writing pedagogy, volunteered at a university writing center, and taught general education composition courses as part of my master of arts in English program. Following graduation, I taught similar sections of introductory composition for three years at a liberal arts college. In this role, I learned to teach writing as a process, provide effective, non-threatening feedback, conference with students, and utilize revision strategies to move students' work forward. In addition, I became acutely aware of the psychological nature of writing and the prior experiences with writing that students carry with them into their academic coursework that can stifle their progress. Some students entered my courses already self-identified as "poor writers" and expected to struggle in the class. Therefore, I learned to plan for and work to overcome deficit mindsets and socioemotional responses to academic writing.

I came to dissertation consulting at City University (a pseudonym) during my second year of $\mathrm{PhD}$ study at the recommendation of the EdD program chair who matched my background in composition with a significant need for writing support for both $\mathrm{EdD}$ and $\mathrm{PhD}$ dissertators in the SOE. During the four year period in which I was consulting at City University, I was deeply entrenched in the culture of the SOE as - at varying points in time-a student, a graduate teaching assistant, a graduate teaching fellow, a graduate research assistant, a member of the EdD Curriculum Committee, and a dissertator. The more I became known as a dissertation consultant among faculty and students in the SOE, the more student referrals to I received. Although my work began strictly copyediting EdD students' dissertations, the further I advanced in my coursework and the more experienced I gained in educational research and teaching in the EdD program at City University, the more methodological and content-based feedback I was able to and began to provide. In addition, as I walked increasingly more dissertators through the dissertation process, I was able to coach students on non-writing aspects of the dissertation process such as: (a) preparing for the proposal and defense, (b) navigating departmental policies and politics, and (c) managing burnout and socio-emotional responses to the dissertation. Thus, over time my role transitioned from a dissertation editor to a dissertation consultant. In this role, I was positioned in a third space (Bhabha, 1994) by the faculty and students. From a faculty standpoint, I was a junior colleague who could check up on, report back, and move students forward in the dissertation process; I could do the messy and time-consuming work of helping students untangle jumbled thoughts and reconfigure them into coherent descriptions of problems of practice, precise methodological reporting, and thoughtful implications. To the EdD students, I was a knowledgeable other yet sympathetic listener, a fellow traveler on the potholed dissertation highway, an insider advocate who had working relationships with faculty, and an experienced guide who had led prior students successfully through the dissertation process.

Early on in my consulting work, I realized that this experience was unique. I noticed - and was told by faculty members - that I and other editors in the SOE were having positive effects on EdD dissertators. Therefore, I developed plans to write about this work with the hope that other doctoral program administrators would consider developing and supporting dissertation consultants in their SOEs. From 2015-2018, I kept detailed notes of my approach, process, salient anecdotes, City University's context, and student outcomes. I wrote analytic memos that reflected my current thinking, questions, challenges, triumphs, and ways my varied background contributed to my success. I draw on these sources to analyze my experience and make claims in the following sections.

\section{SETTING}

The EdD program at City University had been established for decades when I was consulting with dissertators, although the program had recently undergone a dramatic transition from a more traditional, PhD-like program to the Carnegie Project on the Education Doctorate framework (CPED, 2019). Some major changes from the traditional to the revised program included moving from a departmental EdD with a major to a school-wide EdD with an area of concentration, from an in-person course format to a hybrid course format, and from a 5-10 year work-at-your-own-pace schedule to a three-year, full-time cohort model with year-round coursework. In the CPED model, the students took two, three credit courses each summer, fall, and spring term. In addition, inquiry as practice (CPED, 2019) became a primary mode of inquiry, which resulted in shorter, practice-based dissertations. Prior dissertations did not require a specific methodology and were book-length. Finally, the revised EdD program began enrolling much larger cohorts (approximately 60 students per year), which was a trend for the first four years of the program when I was consulting. The students in the traditional EdD program had primarily been PK-12 teachers and administrators or higher education administrators. The new program continued to attract similar candidates but also included new areas of concentration such as STEM and health and physical activity, which provided new opportunities for those in government and research sectors as well as community leaders.

Before and after the redesign of the EdD program, there was a significant need for writing support for EdD students. Many of the students had not taken an academic writing course since their undergraduate career, and they were not required to take one in either the traditional or the revised program. At one time there was an optional dissertation writing seminar available to all doctoral students; however, this course was designed primarily for accountability purposes rather than as an advanced composition course.

The transition to the CPED framework, along with the addition of new program tracks for students who many not have previously considered an EdD, resulted in ballooning enrollments and a strain on program faculty. When I was consulting, the SOE had not hired 
new EdD faculty to manage the increased enrollment (a significant ethical concern), which contributed to the existing need for dissertation writing support. The 2016-2017 academic year is a particularly striking example. During this academic year, I worked with $13 \mathrm{EdD}$ dissertators (and had to turn away other students because I did not have the capacity to help them), which was nearly $20 \%$ of the students in that cohort. As I was not the only dissertation consultant in the SOE at City University at the time, the percentage of students who obtained writing assistance from that cohort was likely higher. While City University's transition to the CPED framework did not inherently cause these tensions, this anecdote illustrates that the need for dissertation writing support can significantly change with the implementation of institutional and departmental reforms, especially those that result in increased enrollment. It also demonstrates that even Research I institutions with strong SOEs enroll underprepared writers who need support at the dissertation stage.

\section{SUPPORTING EDD DISSERTATORS}

In this section, I detail my academic and professional backgrounds and offer three reasons for my success as an EdD dissertation consultant: (a) my experience teaching academic writing, (b) my grounding in educational research and experience coteaching with EdD program faculty at City University, and (c) my willingness to acknowledge and engage EdD students' socioemotional needs during the dissertation process. I argue that $\mathrm{PhD}$ students with similar strengths and dispositions would be viable candidates to engage in this work.

\section{Grounding in Composition}

My experience teaching composition to undergraduates has close correlations to working with dissertators. These include: (a) teaching principles of academic composition and source-based argumentation, (b) framing writing as a process, (c) providing feedback, (d) discussing revision strategies, and (e) providing socioemotional support. When I was an English instructor, the content and skills I was teaching were nearly identical to those that I introduced to and reinforced with the dissertators I was coaching, although at an advanced level for the latter. One coaching practice I used with my undergraduates was a questioning strategy. Once students had a topic, I would begin asking questions about their topics or arguments-often playing devil's advocate-then join them in imagining what a particular project could look like, all the while urging them to take ownership of the topic, direction, and outcomes of the writing. I found this to be markedly similar to helping EdD students develop their research questions and study design. The EdD students had topics they wanted to study and sometimes research questions, but they often struggled to operationalize those ideas into a research design or proposal. Having a coach with whom to talk through ideas, ask constructive questions, and imagine what a study could look like helped the students clarify and focus their thinking. Sometimes, dissertators simply needed help moving from one step to the next to narrow the scope of the study, confront the realities of conducting said study (i.e., time, effort, skills needed), and set the goals of the project.

My experiences teaching composition contributed to my initial willingness to engage in dissertation consulting, provided a framework for my work that was research-based and grounded in best practice, and gave me ethos that helped me build trust with both students and faculty. Because dissertation consulting required additional genre and content-specific knowledge that I did not have from teaching freshman composition (e.g., writing a literature review or reporting qualitative data analysis procedures) it was critical for me to continue developing my knowledge of the dissertation genre and educational research through my own coursework and research.

\section{Grounding in Educational Research and the CPED Framework}

While teaching composition positioned me to assist with dissertation writing, my experiences in educational research as a $\mathrm{PhD}$ student transformed my work from dissertation editing to dissertation consulting because they bolstered my knowledge of methodology. This research engagement came from three sources: coursework, teaching, and research with SOE faculty. As a PhD student, I took courses in disciplined inquiry, quantitative and qualitative methodology, and data collection and analysis. In these and independent study courses, I learned principles of educational research and then designed, conducted, and reported small pilot studies. Later, I assisted a team of EdD faculty in developing and co-teaching two practitioner inquiry courses. In these courses, we introduced inquiry as practice (CPED, 2019), data collection methods, and data analysis procedures. Because of my work in the EdD program, I was invited to be a graduate student representative on the EdD Curriculum Committee that was tasked with reviewing and revising methodology courses in the EdD program. At the end of my program, I worked as a graduate research assistant to SOE faculty on a National Science Foundation grant-funded project where I engaged in data collection, preliminary data analysis, and dissemination activities.

These experiences had a noticeable and impactful effect on my ability to coach the methodological components of the dissertation. For example, as part of my coursework I took a research interviewing course where I learned about interviewing as a data collection method and designed a pilot study that involved developing a protocol, writing interview questions, conducting and transcribing interviews, and coding the transcripts. The next semester, I worked as a graduate assistant conducting interviews and coding transcripts for a SOE faculty member. Engaging in my own and others' research bolstered my knowledge and confidence of developing, conducting, and analyzing interviews. Although I was far from an expert interviewer, these experiences allowed me to coach dissertators who using interviews, give practical advice, and share resources that I had utilized. I naturally applied my coursework and experiential learning via feedback and in conversations with EdD dissertators by using the questioning strategy I detailed earlier and offering suggestions for next steps, resources, and questions to ask the dissertation chair.

Furthermore, I often conferred with EdD students in class for the EdD courses I co-taught. These conferences helped me identify common questions, misunderstandings, challenges, and socioemotional needs that the students had (e.g., narrowing topics, identifying problems of practice, aligning the elements of the research design), so I learned to expect these questions in my consulting work and was prepared to address them. For example, students often proposed larger studies than were feasible for a dissertation and resorted to case study design irrespective of their research questions or the scope or purpose of the study. Teaching in 
the program also provided me with knowledge of the CPED framework and common programmatic language. For example, I understood inquiry as practice, a problem of practice, and a dissertation in practice (CPED, 2019) because I had taught these concepts, and I could (and did) clarify them for dissertators when necessary. Again, conferring in class and using program language translated naturally to my consulting work, and, as I was consulting at the time, it is likely that my experience consulting improved my in class conferences for the same reasons. Because I understood the conceptual framing of the EdD dissertation under the revised CPED framework, I was able to help students see the end product and goals of their dissertation and help them shape their study to meet those goals.

\section{Acknowledging and Supporting Socio-Emotional Needs}

Prior research has demonstrated that doctoral students need and benefit from socio-emotional support at varying stages of their program (Hunter \& Devine, 2016; Rogers-Shaw \& Carr-Chellman, 2018). The EdD dissertators at City University were no different, and my acknowledgement of that and willingness to provide socioemotional support developed trust and positive working relationships that supported students' progress. Not all, but most of the EdD students were referred to me for dissertation writing support from their chairs or committee members. Students were often surprised at the suggestion to obtain an editor, because they had completed their coursework without realizing their writing skills needed improvement. A few students were languishing ABDs and were about to time out of the program and not graduate. The students in the redesigned CPED program were all constrained by time due to the shortened program structure. Therefore, in addition to normal stress that doctoral students experience (see Mackie and Bates (2019)), many EdD students at City University demonstrated elevated needs for socio-emotional support. My approach to this was to acknowledge students' socio-emotional responses to the dissertation process such as burnout, frustration, fear, and even loneliness, listen empathetically, and then offer hope by relaying my success guiding other students through their dissertations. I began each job with an initial phone call to introduce myself and hear the student's story. During the planning and writing process, I often met students inperson, through video-conferencing, texting, or phone calls to check in and talk through feedback. While I did not realize it at first, dissertation consulting became a highly relational experience, and I believe that developing positive relationships with students and offering socio-emotional support bolstered the academic support I provided and spurred students onward. Research on the effects of positive interpersonal relationships on doctoral student persistence (e.g., Ruud et al., 2018) would seem to support this finding. For example, Lev, an EdD candidate, had been ABD for five years when I began working with him. At that time, Lev was disconnected from the university; he was working full-time and not taking classes or otherwise engaged with City University. He was also not making progress toward his dissertation. Throughout our collaboration, Lev checked in with me frequently to share his progress, vent frustration, and even ask questions about my own degree progress. He often commented that family and friends did not understand his struggle, because they had not been through a doctoral program. However, knowing that someone else was going through the dissertation process with him was comforting and motivating. I was quick to offer praise when he was moving forward, suggestions when he was stuck, and an ear to listen when needed. Within a year of our collaboration, Lev completed his dissertation and graduated. This anecdote demonstrates how responding to socio-emotional needs, in addition to coaching, offered a site of respite, motivation, and guidance for a dissertator who was stalled and disconnected. While some students might require more socio-emotional support than others, I found that providing this type of support was nearly as important as writing or methodological feedback.

\section{Leveraging PhD Students}

Like Lev, many of my dissertators expressed that they did not feel they had anyone else to turn to for the specific types of support that I offered: (a) personalized academic writing and editing feedback, (b) methodology coaching, (c) and socio-emotional support. While City University had a writing center, library workshops on dissertation writing, and some faculty who held advisee meetings and encouraged peer writing groups, these organizational supports were not enough for the needs of many EdD dissertators. While other SOEs may offer similar affordances, they might also lack sufficient organizational supports for EdD dissertators. Given this context, I argue that CPED institutions as well as other SOEs with doctoral programs can leverage PhD students to support EdD dissertation writing. This model works for several reasons. First, the PhD track has traditionally differed from the EdD track in that it prepares future researchers rather than practitioner-leaders (Butin, 2010), so PhD students are likely to take research courses and have opportunities to engage in research independently and with SOE faculty. They may also identify as burgeoning educational researchers and have professional goals that include continued engagement in research post-graduation. In tandem with their research orientation, advanced $\mathrm{PhD}$ students would have experience writing about research via coursework, program benchmarks, comprehensive exams, conference proposals, journal articles, and their own dissertation proposals and manuscripts. Thus, they are positioned well to support, not direct, the research and research writing components of the dissertation. Second, although $\mathrm{PhD}$ students may have left the school site to complete their degree, many come from professional backgrounds that involve PK-12 schools or higher education sites. This insider knowledge can benefit EdD students as they develop and frame their studies as well as interpret findings and proffer implications. Third, advanced $\mathrm{PhD}$ students are positioned to become engrained in the SOE culture and know the dissertation processes, procedures, and expectations as well as the faculty and their orientations, preferences, and feedback styles. Therefore, they can help EdD students navigate the sociocultural, academic, and political landscapes of the SOE that affect all doctoral candidates.

$\mathrm{PhD}$ students with backgrounds in teaching or tutoring academic writing or current or former teachers may be particularly well-positioned to become dissertation consultants, especially as they gain experience in educational research methods through their coursework or graduate assistantships. PhD students with backgrounds in composition but not educational research could still assist in the writing of the dissertation but should resist offering methodological commentary. When matching dissertation consultants with EdD dissertators, program administrators should take great care to consider the fit between the consultant's and the student's methodological and epistemic orientations as well as the consultant's experience with the dissertator's methodology. Consultants should be paired with dissertators who are doing studies 
that fall within their realm of methodological knowledge and experience ${ }^{2}$. Dissertation consultants must have a firm grasp on academic writing, Standard American English grammar and punctuation, educational research methodology, and first-hand experience in educational research. Finally, they must not only know this content but be able to teach it; thus, they should develop or refine coaching skills related to designing, conducting, and reporting research as well as dispositions that include patience, empathy, and encouragement.

\section{DISCUSSIONS AND IMPLICATIONS}

In this section, I first describe the potential mutual benefits to EdD students, PhD students, SOEs, and local schools and communities that could arise from partnerships between EdD and $\mathrm{PhD}$ students due to dissertation consulting. Next, I discuss two important considerations for SOEs that are interested in implementing this intervention: (a) training for dissertation consultants and (b) funding for PhD students who take up this work.

\section{Mutual Benefits}

Utilizing PhD students as organizational writing supports for EdD dissertators can result in numerous benefits across parties. First, and most importantly, as my work at City University demonstrated, dissertation consulting can result in increased retention and graduation rates for EdD students; all 35 students I worked with completed their dissertations and graduated. It is certainly possible that those students could have graduated without support, but the opposite is also true. Current estimates dismally suggest that between $50-70 \%$ of EdD students and $50 \%$ of $\mathrm{PhD}$ students do not graduate (Council of Graduate Schools [CGS], 2010; Lowery et al., 2018). However, Bolli et al. (2015) found that providing writing instruction in coursework is associated with increased graduation rates for social sciences PhD students; it is likely that this effect could be the same for EdD students. I argue dissertation consulting can be a proxy for writing coursework where none is provided.

Second, CPED is currently leading the initiative for reimagined EdD programs across the country, and many SOEs are revisiting existing EdD programs or developing new ones (Perry, 2015). Therefore, there are exciting opportunities for newly-minted PhDs to work in EdD programs. However, authentic engagement with EdD students is hard for PhD students to come by; therefore, dissertation consulting can be a valid and valuable pathway to accessing this population and building a professional portfolio. Through dissertation consulting, PhD students obtain advisor-like coaching experience, learn where and how EdD students struggle with the dissertation, and develop strategies for supporting them. $\mathrm{PhD}$ students who consult in CPED institutions will learn the framework and know CPED's objectives, goals, and language, which would benefit multiple parties if they move to another CPED institution after graduation.

Third, collaborations between $\mathrm{PhD}$ and EdD students can support existing and stimulate new school-university partnerships between researchers and practitioners who share common interests. Christianakis (2010) asserted that these partnerships can "build reciprocal alliances" that can break down "knowledge hierarchies," bridge the theory-practice gap, and engender collaborations that influence educational policy and reform (pp. 111, 114). Developing relationships with key district personnel may open doors for $\mathrm{PhD}$ students to conduct research in schools while positioning practitioners as researchers can push back against notions of practitioners as consumers, not producers, of research (CochranSmith \& Lytle, 2009). Pairing PhD and EdD students can benefit schools and communities by melding the knowledge and skills of aspiring researchers with the professional wisdom of school leaders as they investigate and address persistent problems of practice.

\section{Developing and Supporting Dissertation Consultants}

Leveraging PhD students as dissertation consultants should be strategic and intentional, and SOEs must attend to two important considerations for this work to be successful. First, while the experiences listed in the prior section may position $\mathrm{PhD}$ students well for this work, it is also imperative that consultants receive initial training and ongoing professional development in several key areas: (a) dissertation research design, (b) EdD programmatic language, norms, and expectations, (c) coaching EdD students, (d) coaching writing, and (e) navigating socio-emotional responses. It is also crucial that consultants have a clearly defined role that delineates boundaries and responsibilities (e.g., Dissertation consultants should not write sections of the dissertation or override the advisor.). This training could be provided by the university writing center, a graduate student supervisor, an EdD program faculty member or administrator, or an experienced $\mathrm{PhD}$ dissertation consultant. Secondly, SOEs should allocate funding for graduate assistantships for dissertation consultants or partner with the writing center to do so. In fact, Bolli et al. (2015) found that fully-funded PhD students are more likely to graduate, so funding dissertation consultants could actually improve outcomes for both PhD and EdD students. SOEs that are experiencing a surge of EdD students, such as City University, could utilize tuition revenue for these assistantships. The number of dissertation consultants could fluctuate depending on the institution's size and enrollment; however, I suggest having at least one consultant who specializes in quantitative methodology and one who specializes in qualitative. Redistributing resources and funding to support this initiative may be necessary, but, given my experience at City University, doing so could result in significant outcomes and positive shifts in graduation and retention for $\mathrm{PhD}$ and $\mathrm{EdD}$ students.

\section{CONCLUSION}

White (2016) and others (e.g., Bertram Gallant, 2016) have been critical of dissertation editors for their predatory practices and completion of the work for which dissertators themselves are responsible. These authors pose an important question: Can dissertation editing be done ethically so that the dissertator is not passing his work off onto someone else and taking credit for it? In

\footnotetext{
${ }^{2}$ For example, I specialized in qualitative methodologies and consulted exclusively with students doing qualitative dissertations.
} 
short, my response is yes. The EdD students I consulted with genuinely worked hard and took responsibility for their studies. Thus, my dissertation consulting was not the students passing their work off on me. Furthermore, most of the students I worked with were referred to me by their committee members, so, at City University, dissertation consulting was sanctioned and appreciated by EdD program faculty and administrators. Finally, the dissertation consulting I did was essentially peer review, and much academic writing goes through the peer-review process. For example, dissertators receive copious feedback from committee members, doctoral students exchange papers in class, journal editors send out article submissions for review and feedback, and authors of scholarly and professional books use editors within the publishing house. Therefore, dissertation consulting as framed in this article follows a scholarly tradition that is utilized in the academic community.

Although various forms of dissertation writing support exist across doctoral programs (e.g., writing courses, writing groups, scholar networks, and writing centers) they vary by institution and may not be sufficient for the academic and accessibility needs of EdD students.

By taking up this initiative in addition to other systemic support options such as writing courses, SOE administrators would provide a much needed organizational support for EdD dissertators while avoiding faculty burnout or having to hire writing support specialists. Dissertation consulting has a strong potential to reduce EdD student attrition and boost graduation rates and even affect $\mathrm{PhD}$ completion through graduate funding streams. Finally, this work could build bridges between $\mathrm{EdD}$ and $\mathrm{PhD}$ programs and offer both groups opportunities to further their professional knowledge and practice.

\section{REFERENCES}

Becker, H. S. (2007). Writing for social scientists: How to start and finish your thesis, book, or article (2nd ed.). University of Chicago Press.

Bertram Gallant, T. (2016). Response to White's 'Shadow scholars and the rise of the dissertation service industry'. Journal of Research Practice, 12(1).

Bhabha, H. (1994). The location of culture. Routledge.

Bolli, T., Agasisti, T., \& Johnes, G. (2015). The impact of institutional student support on graduation rates in US PhD programmes. Education Economics, 23(4), 396-418. https://doi.org/10.1080/09645292.2013.842541

Booth, W. C., Colomb, G. G., Williams, J. M., Bizup, J., \& FitzGerald, W. T. (2016). The craft of research. University of Chicago Press.

Brooks-Gillies, M., Garcia, E. G., Kim, H. S., Manthey, K., \& Smith, T. (2015). Graduate writing across the disciplines: Introduction. Across the Disciplines, 12(3)
Butin, D. W. (2010). The education dissertation: A guide for practitioner scholars. Corwin.

Carnegie Project on the Education Doctorate. (2019). The CPED framework. Retrieved from https://www.cpedinitiative.org/the-framework

Christianakis, M. (2010). Collaborative research and teacher education. Issues in Teacher Education, 19(2), 109-125.

Cochran-Smith, M., \& Lytle, S. L. (2009). Inquiry as stance: Practitioner research for the next generation. Teachers College Press.

Council of Graduate Schools in the U. S. (2010). Ph.D. completion and attrition: Policies and practices to promote student success. Council of Graduate Schools.

Hunter, K. H., \& Devine, K. (2016). Doctoral students' emotional exhaustion and intentions to leave academia. International Journal of Doctoral Studies, 11, 35-61. https://doi.org/10.28945/3396

Kamler, B., \& Thomson, P. (2008). The failure of dissertation advice books: Toward alternative pedagogies for doctoral writing. Educational Research, 37(8), 507-514. https://doi.org/10.3102/0013189X08327390

Kennedy, B. L., Altman, M., \& Pizano, A. (2018). Engaging in the battle of the snails by challenging the traditional dissertation model. Impacting Education, 3, 4-12. https://doi.org/10.5195/IE.2018.27

Lowery, K., Geesa, R., McConnell, K. (2018). Designing a peer-mentoring program for education doctorate (EdD) students: A literature review. Higher Learning Research Communications, 8(1). https://doi.org/10.18870/hlrc.v8i1.408

Mackie, S. A., \& Bates, G. W. (2019). Contribution of the doctoral education environment to $\mathrm{PhD}$ candidates' mental health problems: A scoping review. Higher Education Research Development, 38(3), 565-578. https://doi.org/10.1080/07294360.2018.1556620

Perry, J. A. (2015). The Carnegie project on the education doctorate. Change, The Magazine of Higher Learning, 47(3), 56-61. https://doi.org/10.1080/00091383.2015.1040712

Queen, R., \& Squires, L. (2011). Writing a dissertation. Journal of English Linguistics, 39(3), 300-305. https://doi.org/10.1177/0075424211415834

Roberts, C. L. (2010). The dissertation journey: A practical and comprehensive guide to planning, writing, and defending your dissertation (2nd ed.). SAGE.

Rogers-Shaw, C., \& Carr-Chellman, D. (2018). Developing care and socioemotional learning in first year doctoral students: Building capacity for success. International Journal of Doctoral Studies, 13, 233-252. https://doi.org/ 10.28945/4064

Ruud, C. M., Saclarides, E. S., George-Jackson, C. E., \& Lubienski, S. T. (2018). Tipping points: Doctoral students and consideration of departure. Journal of College Student Retention: Research, Theory \& Practice, 20(3), 286-307. https://doi.org/10.1177/1521025116666082

Russell, D. R. (2002). Writing in the academic disciplines: A curricular history (2nd ed.). Sothern Illinois Press.

Switzer, A., \& Perdue, S. W. (2011). Dissertation 101: A research and writing intervention for education graduate students. Education Libraries, 34(1), 4-14. https://doi.org/10.26443/el.v34i1.299

White, J. L. (2016). Shadow scholars and the rise of the dissertation service industry: Can we maintain academic integrity? Journal of Research Practice, 12(1), 1-9. 